\title{
Coming Home: Finding Our Space of Innocence Through Sagŭk Films
}

Saena Dozier*

The emergence of South Korea as an economic super power has coincided with the rise in popularity of the sagŭk film genre. This is surprising because, for decades, sagŭk, a genre of film set in the premodern era based on real historical events and the lives of actual historical figures albeit blended with strong fictional elements, has been marginalized and dismissed as a "dead genre." In this review, I discuss the dominating operative mode of the sagŭk films, melodrama, and its essential feature of a "space of innocence" to explain its role in resuscitating the sagǔk film genre. I argue that organically emerging spaces of innocence within the diegesis of sagŭk film contributes to its becoming not only commercially viable but also one of the most popular genres in South Korea as well as outside of Korea, garnering global recognition. ${ }^{1}$

The space of innocence within the diegesis of recent South Korean sagŭk films is noteworthy in that, unlike a traditional definition, it is not bound to a particular space or time. Instead, an original status of virtue and innocence is manifested in personages in historical fiction. People

Ph.D. Candidate, Department of Asian Languages and Literatures, University of Minnesota, Minneapolis, Minnesota, USA

1 Diegesis is defined as, "[i]n a narrative film, [diegesis is] the world of the film's story. The diegesis includes events that are presumed to have occurred and actions and spaces not shown onscreen" from David Bordwell and Kristin Thompson, Film Art: An Introduction, 10th ed. (New York: McGraw-Hill, 2013), 501. 
who are historical and fictional characters in sagŭk films become the space of innocence. Contemporary sagŭk films elucidate the ideal humanness within people of the imaginary past, making them the locus of virtue. Ideal humanness in the characters then shapes and governs all human relations and social interactions in the diegetic world of the film. These relationships are among kings and subjects, family members, lovers, friends, neighbors, and even strangers. By doing so, the sagǔk films present desirable human qualities as a space of innocence which is no longer available in a late capitalistic society such as South Korea. At the same time, these idealized traits offer pleasure to audiences who see a restoration of innocence in humanness - something contemporary viewers imagine to be forever lost living under what Rob Wilson calls the "killer capitalistic" society of South Korea. ${ }^{2}$ With the analysis of a space of innocence as foundational to sagŭk phenomenon, I also demystify and redefine the notion of nostalgia and discuss how nostalgia is expressed in contemporary sagŭk films. With melodrama, nostalgia fundamentally shares the substantive desire to return to a space of innocence, idealized in one's imagination among possible social interactions within a collective community. This ideal state, as I define in this review, supposedly existed in rural communities before the urban degradation of a late capitalistic society.

\section{Melodrama and Space of Innocence}

Melodrama is a mode of literary, theatrical, or filmic representation characterized by heightened sentimentality, emotion, and pathos. The social function of melodrama in Korean cultural art forms has a long and complicated history together with its rival, realism. In the 1930s, melodrama was mobilized to inculcate Japanese nationalism in the local Kore-

2 Rob Wilson, "Killer Capitalism on the Pacific Rim: Theorizing Major and Minor Modes of the Korean Global," Boundary 2 34-1 (Spr. 2007): 115-33. 
an population. Moreover, melodrama was used in both South and North Korea as one of the most effective means of propaganda during the Cold War era. Melodrama is particularly effective at politicizing the body, provoking pathos and emotional identification through the visceral depicting of suffering bodies. The power and misuse of melodrama has gained much attention in Korean film scholarship. ${ }^{3}$

Film scholar and expert in the study of melodrama, Linda Williams, established that one of the most inherently distinguishable features of melodrama is its tendency to begin and to end in a space of innocence. ${ }^{4}$ In the case of American stage melodrama, gardens and rural homes are often portrayed as places of such uncorrupted innocence. ${ }^{5}$ The narrative then unfolds as this fleeting state of virtue is soon spoiled by a villain. It is the melodrama's clear goal to recover and return to this initial moment of virtue and the locus of innocence at the end of its narrative. If the protagonist can somehow return to this represented home, the narrative ends happily.

But why does the audience desire to find the space of innocence in the distant past of a nation such as Chosŏn rather than a purely fictive time and space where imagination could be less constricted by historical facts and more creative in fashioning an inventive space of innocence? Here I am referring to examples of space of innocence in entirely fictive loca-

3 Most notable work on this issue is Kathleen McHugh and Nancy Abelmann, ed., South Korean Golden Age Melodrama: Gender, Genre, and National Cinema (Detroit: Wayne State University Press, 2005).

4 Linda Williams, "Melodrama Revised," in Refiguring American Film Genres, ed. Nick Browne (Berkeley: University of California Press, 1998), 65; Linda Williams, Playing the Race Card: Melodramas of Black and White from Uncle Tom to O.J. Simpson (Princeton: Princeton University Press, 2001), 28.

5 Classic stage melodrama, Peter Brook remarks, "typically opens with a presentation of virtue and innocence, or perhaps more accurately, virtue as innocence." The audience sees this virtue and takes pleasure in itself. Peter Brooks, The Melodramatic Imagination: Balzac, Henry James, Melodrama, and the Mode of Excess (New Haven: Yale University Press, 1976), 29. 
tions such as Shangri-La in the Lost Horizon (Frank Capra, 1937), or from more recent examples of Pandora in Avatar (James Cameron, 2009), and Urk from the popular South Korean television series, The Descendants of the Sun (2016). Williams observes that melodrama inherently uses older spaces of innocence rather than unknown, new spaces of innocence as it seeks to recover "the maternal place of origin" such as a childhood home or the distant past of a nation. ${ }^{6}$ Even if we never possessed virtue and innocence, we like to think we once possessed it in childhood or in the distant past of the nation. Melodrama is infused with nostalgia for a home.

Most sagŭk films produced after the year 2000, however, do not present premodern Korea as a locus of virtue, a place which should be "a maternal home" for the nation. Korea's past is a continual history of trauma, subjugation, and strife; there are no "good old days" to yearn for. So, in sagŭk, nostalgia is not targeted for a different temporality or location. The historical background of sagǔk films often depicts turbulent moments of history filled with collective and personal trauma. The place itself is never a prelapsarian Garden of Eden. Instead, a recurring narrative theme of contemporary sagŭk is how paeksŏng model humanness and social connectivity to the higher classes under historical circumstances that rendered a complete breakdown of human relations. ${ }^{7}$ One of the transformative traits of contemporary sagŭk cinema is that recent sagŭk films seek to elevate and make meaningful individuals from underprivileged classes including women and children by telling their everyday life stories under an oppressive social structure, making them a constitutive

6 Williams, "Melodrama Revised," 65; Williams, Playing the Race Card, 28.

7 This old collectivist term paeksŏng refers to ordinary people who were subjects and represents a lower social status and classification. Its literal meaning is "'hundred names' or the 'common people,' which is used in contrast with officials (kwallyo) or official families (sajok)." Clark Sorensen, "National Identity and the Creation of the Category 'Peasant' in Colonial Korea," in Colonial Modernity in Korea, ed. Gi-Wook Shin and Michael Robinson (Cambridge: Harvard University Asia Center, 1999), 295. 
part of history. ${ }^{8}$ Earlier traditional sagŭk films and TV dramas from the 1970 s to the mid-1990s almost exclusively invested in the stories of ruling classes and an elite society of monarchs and dignitaries. Paeksŏngbased stories were neglected as historically insignificant. In post-2000 sagŭk, fictional characters of historically marginalized groups including peasants, women, and children are rediscovered as their humane qualities, rather than their heroic achievements for the nation, are the driving force of the narrative.

Choo Chang-min's 2012 mega hit sagŭk film, Gwanghae: Wang-I Doen Namja (Masquerade), for example, uses the historical background of the reign of King Gwanghae (1608-1623). During the earlier period of his reign, Chosŏn was slowly being reconstructed out of the devastation from the Imjin Wars (Toyotomi Hideyoshi's 1592-98 invasion). Chosŏn was not only recovering from physical destruction and the utter collapse of political and social systems but also from the haunting memories of violations of humanity. Henry H. Em writes that because of damaged lands, conscription of men, and the displacement of innumerable people, the drastically reduced amount of harvested grain caused active cannibalism. Sónjo sillok records cases of murder and cannibalism even among family members in the face of calamity. ${ }^{9}$

8 This trend of rediscovering paeksŏng is also evident in television sagŭk dramas. According to the result of Jo Mi-Sook's empirical research, between the years 2000 and 2012, there were 40 historical TV dramas produced that were set between the Chosŏn period and the early 1900s. Among these series, 42.5 percent either dealt with success stories of actual commoners from history or the series focused on the everyday experiences of fictional characters who, while not actual historical figures, are used to represent the imagined paeksŏng of the time period. Jo Mi-Sook, "Yŏksa Chŏnyuŭi Se Kaji Pangsik: P'yujŏnsagŭk Sok Wangŭi Sŏsarŭl Chungsimŭro (A Study on Three Different Ways of Creating by Using Historical Culture Content: Focusing on the Narration of the King in the FusedHistorical-Dramas)," Han'gungmunyebip'yŏngyŏn'gu (Journal of Korean Literary Criticism) 40 (2013): 275.

9 Henry Em, The Great Enterprise: Sovereignty and Historiography in Modern Korea (Durham and London: Duke University Press, 2013), 179. 
The fictional circumstances in Gwanghae are not much better. In the beginning of the film, spectators are immediately taken into an anxietyfilled court under the paranoid King Gwanghae (played by Lee Pyŏnghŏn [or Byung-heon]). The palace is a place of fear and conspiracy. Yet, with the entrance into the court of a lowly peasant, Hasŏn (again played by Lee Pyŏng-hŏn) disguised as the king, its atmosphere changes from one of fear and mistrust to that of high morale. Hasŏn is a jester who entertains aristocrats at the tavern in Hanyang, the capital of Chosŏn. With an exceptional likeness to the monarch, Hasŏn is then recruited to act as a decoy for assassins. However, when the king is poisoned with poppies and in recovery, Hasŏn gets caught up in the King's affairs. Hasŏn acts as the official king. Although he begins by awkwardly filling this role, lowly Hasŏn's humane personality and affection for people around him change the mood of the once oppressive court and begin to build mutual trust. Within the diegetic space of Gwanghae, the audience finds ideal human qualities and meaningful relationships restored through historically insignificant individuals: Hasŏn; the food taster, Sa Wŏl; the King's personal bodyguard, Captain Do; and Chief Eunuch Cho.

Hasŏn begins to voice his own opinion to solve intricate political and foreign relations problems, and unlike the "real" King Gwanghae, he makes decisions that will improve the wellbeing of the paeksong of Chosŏn. While Hasŏn is not a legitimate king, he is a genuine ruler the paeksŏng desire. However, Gwanghae's recovery puts Hasŏn's life in danger. Gwanghae plans to kill Hasŏn for corrupting the king's throne with his "lowly" body. Sa Wŏl and Captain Do sacrifice themselves to protect the personified icon of the space of innocence, which Hasŏn represents, and save it from the corrupt social order of Chosŏn. This sacrifice is particularly revolutionary for Captain Do, whose firm belief was to defend the customary laws of the royal court. Captain Do dies as he helps Hasŏn, ensuring his escape from the royal order. When asked why he is willing to die to protect "the fake one," Captain Do answers, "He may be the fake king to all of you but he is the true one for me." The film Gwanghae transforms previously considered historically insignificant 
paeksŏng such as Captain Do and Sa Wŏl into key protagonists that possess the ideal human qualities and connective social interactions, challenging the historically-conditioned society, and in doing so, preserve the space of innocence emblemized by Hasŏn.

\section{Demystifying and Redefining Nostalgia}

The cover story in a recent issue of Smithsonian magazine (June 2017) features a futuristic South Korean society where nearly every aspect of human interaction is now mediated by technology. The convergence of humanity and technology is manifested in examples of smart apartments and assistant robots. Seoul's smart-living apartments are truly smart: they inform the residents of the arrival of guests into the building's garage using a sensor to read guests' license plates. A sensory monitor warns a resident to take an umbrella before he or she leaves the apartment. With Bluetooth's accessibility, a resident can wirelessly open the door, order an elevator, and scan a visitor's face from the bathroom stall. Technological advances are also changing social responsibilities. Life-like assistant robots are developed to provide services for elders. Scientists expect that these robots, who can express about twenty emotions, including fear, joy, and anger, will offer not only basic care for elders but also simulate true companionship. The writer of the article, Gary Shteyngart, maintains that South Korean society is like an outpost from the future.

Yet these technologically savvy and future-oriented South Korean consumers desire to experience the distant past. Filmmakers capitalize on that desire with the production of sagŭk films. Scholars and critics often explain the motivation behind the creation and consumption of dramatization of the past as a modern nostalgia culture. If the popularity of sagŭk films is propelled by a modern nostalgia culture, the definition of nostalgia needs to be examined and studied. Nostalgia is generally understood as an intense yearning for temporality; it is defined as sentimental idealization of a past - the birth of the nation, the emergence of its people, or 
the rise and fall of national heroes. Further, nostalgia is a sentiment generated by a deep sense of loss of familiar space as the word nostalgia comes from two Greek roots: nostos, return home, and algia, longing. This "home" can refer to an actual home that no longer exists but existed in the past, or it can also mean an abstract sense of home that exists in a person's memory or imagination. Nostalgia is also collective and communal grieving rather than an individual condition. Unlike melancholia, which is an individual affect, nostalgia is an affective yearning for a community with shared and collective memories. People who experience nostalgia are displaced individuals or a displaced group of people who belong to a larger community.

Nostalgia shares the dynamic common to melodrama, which begins and wants to end in a space of innocence. The represented "home" is in fact a space of innocence. I suggest the longevity of melodrama as a mode as well as a genre is closely linked to its appeal in addressing nostalgia's focus on recovering virtue and innocence at the end-returning to an extrapolated form of collective "home." In Korean sagǔk, nostalgia is not a yearning for a return to a home that had actually existed historically, but rather a psychological longing to escape, that is, to project one's prospective hopes and desires into an imagined past. Nostalgia involves a continual search for a time where we imagine that desirable humanness once existed. As members of the postmodern mankind, spectators find these ideal human qualities and relationships in historical fiction, specifically in the premodern past. Nostalgic persons do not wish to re-experience the relatively recent historical past of violence and aggression against humanity - evils such as holocaust, slavery, imperialism, and genocide, to name a few. The memory of the real past renders a person speechless and guiltridden. No one who is truly nostalgic wants to return to that past. Nostalgia is a form of romantic fantasy for a space of innocence; an escape from the frustrations and disappointments with the contemporary situation.

Often the contemporary situation is one of alienation and displacement - and I would argue, this is the case with South Korean culture today. In 1903, Georg Simmel wrote, “The Metropolis and Mental Life.” At 
the turn of the century, Simmel lamented the rapid urbanization and the changing social urban life overflowing with blasé attitudes. People were captive to the new notion of measurable time, working under the clock. Everything in the city was quantitatively measurable, including human interactions. Qualitative value diminished; everything was reduced to quantitative value. Human interactions were shortened and transactional. One could no longer find warmth and connection in personal involvement in small communities. It was this social condition that alienated individuals living among the masses. Superficiality and indifference were governing all human interactions in the city. Nostalgia is grounded in a modern rebellion against ruthless, killer capitalism. One hundred and fourteen years have passed since the publication of Simmel's essay. Gary Shteyngart from Smithsonian writes that despite South Korea's financial and technological achievements, "the mood is not one of luxury and happy success but of exhaustion and insecurity." $"$ Due to extreme competition in achieving perfection in every aspect of personhood-whether that is physical perfection or intellectual perfection from a very young agesocial urban life in the metropolis of Seoul is characterized by disconnected human interactions. The social phenomenon of "doing everything alone"-honbap (eating alone); honsul (drinking alone); and honhaeng (traveling alone) - and preferring to interact solely with technology only aggravates anxiety, frustration, and deeper alienation. Post-2000s sagŭk films articulate the desire for a kind of collective space of innocence and enable viewers to project their aspirations for an ideal human community into that space, offering a stark contrast to the alienating social culture within their own contemporary world. Those of us today who feel perpetually displaced by the alienating urban life of the metropolis long for a space of innocence where humanity, kindness, and connectedness prevail. Sagŭk films offer us this home.

10 Gary Shteyngart, “The Bots,” Smithsonian, June 2017, 71. 
198 Coming Home: Finding Our Space of Innocence Through Sagǔk Films

\section{Filmography}

1. Choo, Chang-min. Gwanghae: Wang-I Doen Namja (Masquerade). 2012. 